The McCarron Lectures*

\section{Lecture 7: Visual Persuasion}

Gary McCarron

Simon Fraser University
Scholarly and Research

Communication

VOLUME 12 / ISSUE 1 / 2021

\begin{abstract}
Lecture 7 examines the application of rhetorical principles to images to see how they are imagined to be persuasive and the ways in which that power of persuasion has been theorized. Whether through discourse or imagery, the notion of persuasion as understood in relation to images is accounted for in a discussion ranging from Plato to William Wordsworth, from Roland Barthes to Paul Messaris, from metaphysics to idolatry.

\section{Résumé}

Le septième cours examine l'application de principes rhétoriques aux images afin de voir comment on a envisagé celles-ci comme étant persuasives et comment on a théorisé leur pouvoir de persuasion. Ce cours rend compte de cette idée de persuasion par rapport aux images, qu’on en ait traité par le discours ou par l'image même, dans une discussion allant de Platon à William Wordsworth, de Roland Barthes à Paul Messaris, de la métaphysique à l'idolâtrie.
\end{abstract}

Keywords / Mots clés : Rhetoric; Symbolism; Illusion; Idolatry; Barthes; Messaris / Rhétorique; Symbolisme, Illusion; Idolâtrie; Barthes; Messaris

\section{Introduction: A thousand words}

This lecture deals with one of the most persuasive aspects of the semiotic landscape of symbols: images. And because this is such an obvious claim-images are persuasive-I will try to explain what it is about images that ultimately makes them persuasive. "A picture is worth a thousand words," according to the expression, but what is it about a picture that makes it more rhetorically potent than spoken or written language? "A good sketch is better than a long speech," Napoleon reportedly said, and even Donald Trump preferred his intelligence briefings to be more visual than discursive. So, it makes sense to look at images to see both how they are imagined to be persuasive-and note the etymology of imagined - and the ways in which that power has been theorized.
Gary McCarron is Associate Professor in the School of Communication at Simon Fraser University. Email: gmccarro@sfu.ca

* Please see Editorial: Syntheses, Reflections, and Conjectures in Scholarly and Research Communication: $\mathrm{SRC}^{1+1}$.

* These lectures are provided with the understanding that when used in class you consider fair use, providing a payment of $\$ 10$ per student. These funds will be forwarded to the author. Please contact Marilyn Bittman, Managing Editor, SRC, for further payment information: bittmanme @shaw.ca 


\section{Scholarly and Research}

\section{Communication}

VOLUME 12 / ISSUE 1 / 2021
But first, a brief digression. Philosophers, politicians, and educationalists have not elevated the image above the word throughout the ages. Even when recognizing the power of the image, some writers have complained that the condition of the visual is overstated when it is elevated over and above the nobility of language. Although a picture might well be worth a thousand words, this equivalence in informational value does not make the picture morally or intellectually superior. Children start looking at picture books and gradually develop more sophisticated and complicated tastes with print books, eventually leaving off pictures entirely. For that reason, some writers have suggested that language constitutes a superior mode of communication. In a developmental sense, we move from pictures to print. In an intellectual sense, we reason more complexly with words than images. In a political sense, we can explain detailed policies with language in ways not possible with the strictly visual.

The poet William Wordsworth was a critic of the visual. This may seem odd to you-it seems odd to me-given a tendency in his early poetry to celebrate the rustic life of the peasant against the literate pretensions of the intelligentsia. Still, Wordsworth (1994) was profoundly unhappy with the 1842 publication of a new periodical called Illustrated London News. He was so unhappy, in fact, that he even wrote a poem in 1846 that was first published in 1850 about the travesty of a news magazine making ample use of images:

\section{Illustrated Books and Newspapers \\ William Wordsworth}

Discourse was deemed Man's noblest attribute, And written words the glory of his hand; Then followed Printing with enlarged command For thought - dominion vast and absolute For spreading truth, and making love expand. Now prose and verse sunk into disrepute Must lackey a dumb Art that best can suit The taste of this once-intellectual Land. A backward movement surely have we here, From manhood, - back to childhood; for the age Back towards caverned life's first rude career. Avaunt this vile abuse of pictured page! Must eyes be all in all, the tongue and ear Nothing? Heaven keep us from a lower stage! (p. 583)

Wordsworth was reacting to something that he felt was going to spoil the evolutionary development of the species, so maybe we should cut him some slack. After all, he did write a good number of poems celebrating nature. But my point is neither to ridicule him nor hold him up as a paragon of the sort of person who champions print, textuality, literacy, and discourse against the encroachments and dangers of visually driven modes of communication. ${ }^{1}$ Rather, I want to suggest that simply saying that images have persuasive power is to risk misdirection; it is necessary to also say that the rhetorical import of images has come to serve political—and, dare I say, propagandistic-purposes throughout the ages. Political ads, for example, often feature images above all else. 
An image of U.S. Supreme Court Justice Amy Coney Barrett holding up a blank notepad at her 2020 confirmation hearing has become a meme, for example, and an image of the moment President George W. Bush's staff informed him about the 9/11 attack in 2001 has achieved an iconic status. Pictures of royalty still sell for considerable sums of money, and celebrities, in many respects, live off their images. So, while Wordsworth may be partly right in suggesting that images take us back to childhood, the real question might be whether we have ever entirely freed ourselves from a propensity to privilege the image over the word.

Let us begin at the beginning with the ancient Greeks. Let us start with Plato.

\section{Plato opposed rhetoric; he also opposed images!}

It is hardly worth stating that imagery can be persuasive, and it is partly because images have such a great capacity for persuasive appeal that Plato opposed them. Plato found images to be untrustworthy because they were mere copies, and he believed that copies were epistemologically and even politically suspect. This view likely strikes modern readers as ludicrous, especially in an age where images both surround and inform us. It is now common knowledge that politics is all about image and industry is all about optics - transnational corporations strive to achieve an appropriate public image. What we look at and how we ourselves look help define our social and personal identities. Everything is tied up with images and appearances, and for Plato to say that images should be abolished because they are mere copies-and, therefore, distractions from the search for eternal, cosmic truth-is outmoded and unhelpful. After all, and as so many have argued, we live in an image-based culture. To abolish images from our world would be to abolish culture.

However, Plato might not be entirely irrelevant. We may live in an imagistic culture, but is it possible that there is still some value in his argument?

Joe Rosenthal's (see Figure 1) photograph of six marines raising a flag in Iwo Jima on Mount Suribachi in Japan is one of the most recognized and important images of World War II. The moment was also immortalized in a film starring John Wayne called Sands of Iwo Jima (Dwan, 1949).

Wayne, now largely regarded as an icon-perhaps an imageof the U.S. military, never actually did military service. This is not a criticism of Wayne, merely an observation that a person can become a significant representation of some cause or event precisely because of the power an image to bind together the reference of the image, in this case, World War II, and the symbol of that image, John Wayne. This relationship testifies to the value of Jean Baudrillard's (1983) argument that an image supersedes the reality of an event, but I do not want to spend time dissecting issues of hyperreality.

I do want to make a few points about Rosenthal's famous picture, and I think it valuable to note that the picture is almost inextricably associated with a film that ultimately 


\section{Scholarly and Research}

\section{Communication}

VOLUME 12 / ISSUE 1 / 2021 transformed a Hollywood actor into an icon of militaristic bravery. But the truth is not found entirely in the image. Indeed, when John Wayne visited a military hospital in Hawaii during World War II, he was booed and hissed by wounded soldiers. So, even though Wayne starred in many war films, the marines in the hospital understood the deceit and manipulation of celebrity culture; as Plato might have argued, they understood that the rhetoric of the illusion might ultimately be a distraction from the truth. It probably did not help that Wayne made the curious choice of donning a cowboy outfit that included spurs and pistols. For these wounded soldiers, this ensemble only reinforced the unreality of the persona he portrayed. Wayne himself was an image, an illusion, a deception, and the soldiers were able to see through the façade.

Sands of Iwo Jima (Dwan, 1949) depicted one of the bloodiest South Pacific battles. The film is especially notable for the fact that director Allan Dwan, who was born in Canada, decided to recreate the iconic image taken by photographer Joe Rosenthal of five marines and a navy corpsman raising the American flag on top of Mount Suribachi during the battle near the film's conclusion. To make the cinematic moment even more realistic and emotionally compelling, he had three of the original marines-Rene Gagnon, Ira Hayes, and John Bradley—appear in the film using the original flag, which the U.S. Marine Corps loaned to the production. Sculptor Felix de Weldon later used the photo to make the Marine Corps War Memorial. ${ }^{2}$

The three marines were already minor celebrities prior to the release of the film. Rosenthal's photograph had been reprinted in numerous sources-newspapers, magazines, posters-and was even used by President Franklin D. Roosevelt as the logo for the Seventh War Loan Drive in 1945. The Pentagon brought the men home and had them tour together as a part of a fundraising initiative.

But what was the real story behind the flag raising, and how did the men respond to their celebrity? Having become poster children for the war, Gagnon, Bradley, and Hayes said they felt like prisoners to the image and the cult of patriotism it inspired. Indeed, patriotism is an especially powerful rhetorical trope, used to motivate people to do all sorts of things; frequently, it is best represented in images rather than words. Hayes and Gagnon became alcoholics; both died young. Bradley rarely participated in ceremonies celebrating the iconic moment of the flag raising, and by the 1960s, he had stopped attending such ceremonies altogether. He was plagued by nightmares, especially in relation to the brutal death of a close friend who had been tortured by the Japanese before being killed. He told his wife, Betty, of his war years only once during their 47-year marriage, and that was on their first date. He gave only one public interview - at the urging of his wife, who said he owed it to his grandchildren - and that came late, in 1985. After Bradley died in 1997, his son, James, investigated the events surrounding his father's time in the military and wrote a book, Flags of Our Fathers (Bradley, 2000), giving an unvarnished account of what really transpired.

Bradley, Gagnon, and Hayes' wartime experience had been transformed into an image of patriotic bravery, but it was largely an illusion. Nonetheless, the Pentagon's publicity machine sold the image so effectively that it erased all traces of the real events. The truth did not promote a collective celebration of America's military might, but the illu-

McCarron, Gary. 2021. Lecture 7: Visual Persuasion. Scholarly and Research Communication, 12(1). doi:10.22230/src.2021v12n1a375 
sion was very effective in doing so. The image was, as Plato would have argued, an absolute distraction from the truth, a rhetorical strategy for making the world see things as they were not.

Ira Hayes left the military after his time as a Pentagon celebrity. He was subsequently arrested dozens of times for drunkenness. His body was eventually discovered face down in his own vomit and blood in an abandoned hut near his home on the Gila River Indian Reserve; the coroner's report said he died of exposure and alcohol. Songwriter Peter La Farge wrote the song "The Ballad of Ira Hayes" to reclaim the man from the illusion the army had used to define him. Many artists have recorded the song, including Johnny Cash, Bob Dylan, and Pete Seeger. ${ }^{3}$

Rosenthal froze time with the blink of his camera shutter, and in freezing time, he cut both the past and the future from the lives of his subjects. One aspect of Roland Barthes' theory of photography is its relation to death-not in the sense that pictures of the past feature people who have long since passed on, but because images reek of unreality. Photography attests to our own mortality. The Rosenthal picture was steeped in death in many ways; it was, after all, a war-time photo. Yet, it is the power of the image that is particularly interesting to us now, the way the picture captured a moment and made it iconic, powerful, captivating, and even uplifting for many. Of course, the status and moral condition of images throughout the ages is a complicated one, and in the course of history, images have been viewed in some contexts with suspicion and in other contexts with reverence. What I have just called the power of images has been a topic of considerable discussion, especially because there seems to be a sense in which the power of the image is thought to exceed the power of the word, that emotion, in other words, can overpower reason. Since the Enlightenment, the prevailing view has been that in a contest between emotion and reason, reason should always be favoured.

But speaking of images as having power-which some would argue can be fetishistic or a journey into reification-does reveal one substantial way that rhetoric has been understood in relation to the image. After all, if images have power-and we generally assume they do-then that power might be understood in the way an image affects us; how the image predisposes us to think; how the image sums up in its compact, iconic form an entire argument, position, or way of imagining. In the case of rhetoric, then, the simplest way to think about images or visuality might not be to note that "a picture is worth a thousand words" but that sight itself is the privileged sense, that seeing is believing, or that you might have to see it to believe it. In this respect, one could effectively argue that Plato is correct: images often do have persuasive power largely on account of their immediacy and the absence of syllogistic construction. I will return to this, but for the moment, it is important to note that whereas an argument intended to persuade must take the time to relate its reasons and spell out its premises, an image is immediate in the sense conveyed by the word's etymology: im-mediate means "nothing in between." In an age of media, the immediate is distinguished from the mediate, and because the immediate bypasses our critical faculties, it is often said that the image has a more direct access to the mind, especially because it could, in Francis Bacon's (1973) language, enlist the affections in an alliance with the imagination to move the will. One reason why images can be frightening, then, is that their condition as unmediated (or

McCarron, Gary. 2021. Lecture 7: Visual Persuasion. Scholarly and Research Communication, 12(1). doi:10.22230/src.2021v12n1a375 


\section{Scholarly and Research}

\section{Communication}

VOLUME 12 / ISSUE 1 / 2021 their immediacy) suggests we are defenseless against their influence. If the image is immediate, we are less able to apply the kind of critical reflection that proves effective in monitoring our responses to discourse. Plato, specifically, was concerned about images because he had little confidence that most people have the capacity to resist their seductive power.

Having described the notion that images have power, I will describe in greater detail the relationship between images and rhetoric. Naturally, the idea of the rhetoric of images-or visual persuasion-is closely related to things such as visual culture and critical theory, advertising techniques, theories of photography, and so on. I cannot address all of these in detail, so I will offer some basic ideas. I will also provide a more detailed and complicated overview of Barthes' ideas about photography. First, however, I will touch on certain historical issues, starting with some short reflections about sight followed by some thoughts on idolatry and ideology. Finally, I will move on to discuss some ideas about visual persuasion.

\section{Seeing things}

The idea of sight as the privileged sense has a long history. As Aristotle noted, sight is the sense most able to reveal the truth. Indeed, the opening lines of Aristotle's (2001) Metaphysics clearly position vision in his philosophy of human nature:

All men by nature desire to know. An indication of this is the delight we take in our senses; for even apart from their usefulness they are loved for themselves; and above all others the sense of sight. For not only with a view to action, but even when we are not going to do anything, we prefer seeing (one might say) to everything else. The reason is that this, most of all the senses, makes us know and brings to light many differences between things. (p. 689)

For Aristotle, sight is an elevated or privileged form of sensual activity precisely because of the combination of pleasure and enlightenment it provides. Imaging, visuality, or just plain seeing is not only pleasurable but, as Aristotle argues, literally enlightening. Though knowledge and vision are, thus, indissolubly linked in his metaphysics, it is important to indicate that Aristotle also leaves room in his comments for delight and love. Sight is the most exalted of all our senses.

These considerations often lead us to view sight as nearly synonymous with knowledge, demonstrated in sayings such as, "I see what you mean." Our institutions tend to privilege sight over the other senses. In a court of law, for instance, eyewitness testimony is valued much more than ear-witness testimony; in fact, something that you hear can be second-hand and, therefore, viewed as hearsay and considered inadmissible as evidence. But what you see can never be second-hand, and it would be a logical contradiction to argue that it was. Vision, to put the point once more, is unmediated or immediate, and in many contexts, including a courtroom, eyewitness accounts are, therefore, generally regarded as trustworthy. Eyewitness testimony is considered more persuasive in a court because it is deemed to be pure, unadulterated, and unmediated.

But is this really true? Is sight an unmediated way of accessing the truth and, therefore, more rhetorically substantial? 
Elizabeth Loftus, a psychologist who specializes in the study of eyewitness testimony, has made a career out of demonstrating in experimental settings that eyewitness testimony is usually far more unreliable than is commonly believed, that people make egregious mistakes when offering testimony in court because they are relying not on what they saw but on what they think they saw. ${ }^{4}$ The distinction is subtle but crucial. The brain, it turns out, is not a digital recording device, and memories are always mediated. Thus, while vision itself may be immediate in everyday practice, memories are not immediate but subject to reconstruction. Moreover, memories tend to colour our thinking with affect; that is, when we reconstruct with memory, we often reconstruct with the added emotional colouring that helps to confirm our impression of the event we are recalling. As the psychologists Carol Tavris and Elliot Aronson (2007) wrote:

Memories are often pruned and shaped by an ego-enhancing bias that blurs the edges of past events, softens culpability, and distorts what really happened.... Over time, as the self-serving distortions of memory kick in and we forget or distort past events, we may come to believe our own lies, little by little. (p. 6)

So, what we see, or think we see, is shaped by memory, and memory is far more unreliable than common wisdom preaches. In addition, we tend to prevaricate-that is, we will sometimes alter our account of things we have seen to preserve the logic of events as we understood them or have come to understand them. Even the images in our minds, then, are liable to the influence of affect. Consequently, our reliance on memories of our visual experience turns out to be contentious. Nonetheless, there is still general agreement among many judicial experts and the public at large that because vision offers unmediated access to the world, our recollections of what we have seen are generally accurate. In other words, we might still regard vision as Aristotle did: a portal to truth and enlightenment.

But the history of sight and vision, and the idea that its immediacy is a mark of pure and unadulterated truth, is a position that has not always found favour throughout the course of history. Indeed, sight and vision have occasionally been denigrated in the history of the West. Aristotle's counsel notwithstanding, vision has sometimes been held forth as inferior to other ways of knowing. Consider, for instance, a well-known story from the New Testament, the story of the apostle Thomas. After Jesus rises from the dead (the resurrection), he visits his disciples on an occasion when one of the disciples, Thomas, happens to be absent. When Thomas returns, the other disciples excitedly tell him about Jesus' visit, but Thomas does not believe that Jesus has risen from the dead and says that he will only believe it if he sees the marks left by the nails on Jesus' hands and puts his fingers into the wound left in Jesus' side by the centurion's spear. The resurrected Jesus comes for another visit and this time, according to the scripture, he goes immediately up to Thomas offering him the opportunity to inspect his wounds. He then says, "Thomas, because thou hast seen me, thou hast believed: blessed are they that have not seen, and yet have believed" (King James Bible, 1977, John 20:29).

In this scriptural narrative, vision is subservient to faith. Jesus proclaims that the testimony of words is the principal source of persuasion (the words of Holy Scriptures, in this case, in addition to the words of the other disciples) rather than the testimony of one's eyes. Faith is thus distinguished as a way of knowing and a way of believing

McCarron, Gary. 2021. Lecture 7: Visual Persuasion. Scholarly and Research Communication, 12(1). doi:10.22230/src.2021v12n1a375 


\section{Scholarly and Research}

\section{Communication}

VOLUME 12 / ISSUE 1 / 2021 opposed to the apparent concrete immediacy of vision. For the believer, faith is the path to salvation, truth, and eternal life. Hence the faithful are commanded to follow their faith wherever it takes them, even if that means discounting the evidence of their own eyes.

It is clear, then, that one reason why religion and science are often at odds is that whereas some religions prescribe a way of understanding that compels the believer to disengage from the world, science claims that genuine understanding can occur only when the truth seeker engages directly with the world. Empiricism and theology rarely get along comfortably. This dichotomy encompasses the conviction-persuasion duality. Empiricism aims to change our understanding by conviction: reasoned arguments, rational discourse, evidence derived from the senses and from experimentation, and so on. Faith does not rely on these sorts of considerations, for faith aims to change understanding through revelation, the suspension of reason, inward reflection, and so on. Thus, faith and science can usually form an uneasy alliance at best (when they are not outright antagonists); they might both fashion themselves as vehicles to truth, but they seem to be heading down different streets-if they are even in the same neighbourhood.

This discussion lands us in a kind of indeterminate space. Whereas Aristotle extols vision as the portal to truth, some key figures in the Christian tradition deny that truth is achievable in this fashion. Moreover, the history of religion across the globe has involved debates regarding the status of truth, precisely as these conflicts have entailed arguments about the status of images and whether representations can be properly related to the main precepts of particular religious worldviews. To put that more plainly, not all religions allow images in their sacred houses, while others are famous for celebrating the visual arts-statues, frescoes, mosaics, paintings, icons-some religions find these objects not merely aesthetically pleasing but as important tools to help bring the faithful into alliance with theological doctrine.

One of the questions that frequently gets asked in discussions of visual rhetoric in relation to religious art is why this debate can become acrimonious to the point that people from one faith tradition might destroy the religious symbols cherished by people in another faith. Or why practitioners of a specific religion might decide that the fundamentals of the faith mandate the elimination of all artistic forms. During the Protestant Reformation, for instance, churches were sacked and sacred symbols were often destroyed, even though Martin Luther remained ambivalent about statues and paintings. Why such hostility? Images are persuasive, and, subsequently, certain religious beliefs call for their destruction.

\section{Idolatry: Can you see what I see?}

Rather than begin with the Christian destruction of the pagan artworks, let us begin in a more contemporary setting. When the Taliban first assumed power in

Afghanistan in 1996, one of its primary tasks was the destruction of the two gargantuan statues known as the Buddhas of Bamiyan (Hawkes, 1996). Despite the fact that Afghanistan was a war-torn and destitute nation, the Taliban made one of its chief priorities the destruction of these icons. The statues, carved in solid rock, were 53 and 30 
metres tall, respectively, and they had stood as guardians of the so-called Silk Road for over 1,500 years. The Taliban tried rockets, mortars, and tank shells. They drilled directly into the statues and filled the heads with dynamite. They set fire to tires that were hauled up to the lips of the statues so the soot and residue would blacken and hide the faces. Finally, in May of 2001, they succeeded in destroying the statues, despite persistent protests from archaeologists, historians, politicians, and concerned citizens from around the world.

Why did they do it? The Taliban was relatively silent on that question, but it is generally assumed that they wanted to destroy the symbols of a thriving ancient empire whose philosophy stood in opposition to the views of the Taliban. Perhaps the reason is unimportant because, ultimately, what we can say for certain is that the icons threatened the government of Afghanistan, although that threat was entirely symbolic. There were likely religious reasons involved in the government's decision, as the statues came from another religious tradition. But it is more to the point simply to indicate that the Taliban felt compelled to expend considerable time, money, and energy on the destruction of images they were opposed to.

The battle between symbols and reality—the battle between theology and science-traditionally contains the question of idolatry. In Judaism, Islam, and Christianity, it is considered a terrible sin to take an image for reality, to worship an image in place of the deity. Thus, waves of idolatry and iconoclasm swept through history. Idolatry is the worship of false idols, or false gods, and can transmute into the worship of images or icons. Iconoclasm is the destruction of images that are used in worship. The Bible is clear on this subject, as God's chosen people are admonished to avoid idols in many sections of the Old Testament, "Ye shall make you no idols nor graven image, neither rear you up a standing image, neither shall ye set up any image of stone in your land, to bow down unto it: for I am the LORD your God" (King James Bible, 1977, Leviticus, 26:1). This passage is even more important:

Their idols are silver and gold, the work of men's hands.

They have mouths, but they speak not: eyes have they, but they see not:

They have ears, but they hear not: noses have they, but they smell not:

They have hands, but they handle not: feet have they, but they walk not: neither speak they through their throat.

They that make them are like unto them; so is everyone that trusteth in them. (King James Bible, 1977, Book of Psalms, 11:4-8)

Note that the author of this scripture warns that people will become like the things they worship, they will become "like unto" the idols they have produced by their own hands. This is important, for not only is it a grave sin to mistake an image for reality but it is also dangerous insofar as it will lead to the further error of objectifying the human subject. This argument is also different from Plato's concern regarding images and the arts generally. Whereas Plato worried that art and imagery can distract us from the central truths of life, the Old Testament scholar worries that people will become more than distracted: they will begin to confuse reality with unreality. They will no longer know an important difference, and this confusion will make them liable to even greater mistakes, such as mistaking a false prophet for the true messiah. ${ }^{5}$ 


\section{Scholarly and Research}

\section{Communication}

VOLUME 12 / ISSUE 1 / 2021
The French sociologist and cultural theorist Jean Baudrillard (1983) suggests an even more complex interpretation for iconoclasm, the hatred that fuels the destruction of sacred images. The iconoclasts' "rage to destroy images," he says,

rose precisely because they sensed this omnipotence of simulacra, this facility they have of effacing God from the consciousness of men, and the overwhelming, destructive truth which they suggest: that ultimately there has never been any God, that only the simulacrum exists, indeed that God himself has only ever been his own simulacrum. Had they been able to believe that images only occulted or masked the Platonic Idea of God, there would have been no reason to destroy them. But their metaphysical despair came from the idea that the images concealed nothing at all, and that in fact they were not images, such as the original model would have made them, but actually perfect simulacra forever radiant with their own fascination. But this death of the divine referential has to be exorcised at all costs. (pp. 8-9)

Baudrillard's (1983) analysis suggests the beginning point of an ideological argument. That is, religious-minded believers have worried for centuries about people's inability to properly distinguish the sign from the referent. In communication studies, we often talk about the necessity of being able to distinguish the map from the territory, the need to be able to avoid confusing a description of something with the thing itself. The communication theorist Gregory Bateson (2000) writes:

In the dim region where art, magic, and religion meet and overlap, human beings have evolved the "metaphor that is meant," the flag which men will die to save, and the sacrament that is felt to be more than "an outward and visible sign, given unto us." Here we can recognize an attempt to deny the difference between map and territory, and to get back to the absolute innocence of communication by means of pure mood-signs. (p. 182)

Bateson is interested in the situation where we know the sign is just a sign, but we take it seriously, nonetheless. Men will, he says, die for the flag. The flag, to use Bateson's (2000) words, is "a metaphor that is meant" (p. 182). In the same way, he says, a sacrament-that is, a religious ritual-is a metaphor that is meant. So, too, would the image be a metaphor that is meant.

What sorts of non-religious illustrations could ground these observations outside of the corridors of faith? One example is that we live in a world dominated by an economy that is itself dominated by money, a metaphor that means just about more than anything. One of the more curious things to realize about money is that it does not exist. This idea is explored in a number of important texts, such as Georg Simmel's (1978) The Philosophy of Money and Niall Ferguson's (2009) Ascent of Money: Financial History of the World. But an argument more directly related to the question of images and idolatry and how these ideas relate to money can be found in Marc Shell's (1982) Money, Language and Thought. According to Shell, money has become an autonomous, self-generating, inconvertible sign - a signifier without a signified. In other words, the history of money is the history of its progressive dematerialization. Though it was once a completely concrete phenomenon, currency is now utterly immaterial. In the early days, the value of the coin was its electrum, the material substance (base metal) from 
which it was made (gold, silver, copper, nickel), and the inscription on the coin was fundamentally unimportant. What guaranteed the bearer the value of the currency in hand was the fact that it was redeemable due to its actual physical value.

The difference between face value (intellectual currency) and substantial value (material currency), however, grew progressively greater and achieved its penultimate rupture with the introduction of paper money. With paper money, face value is the only value, for the substantial value of paper is virtually nil. Consequently, although we live in a world dominated by the economy, and although the economy is dominated by money, money itself has become entirely symbolic, a representation of labour power in symbolic form. And with the advent of debit cards, credit cards, and electronic currency, we have reached the point where, as Shell (1982) writes, "the matter of electronic money does not matter" (p. 1). In short, money is an image that has attained the status of reality: it is an idol.

Let us reconsider the connection between the idea of currency and notions regarding images in religious thinking, specifically the Hebrew tradition. In Hebraic thought, it is considered a form of false consciousness to misconstrue the relation between matter and spirit; hence, the Hebrew Bible distinguishes between Israelites and Gentiles on the basis that Israelites prohibit the material representation of their deity. In other words, the early Israelites did not want to confuse matter, as in the form of images, icons, or other physical representations, with spirit or the divinity-they were careful never to confuse the map with the territory. Hence the distinction between Gentiles and Israelites was drawn according to the relation each had with the dichotomy between matter and spirit. The early Israelites recognized that sensual things are an inherent attraction to people, that we are inclined, in other words, to value the object rather than the idea or collection of ideas for which it stands. The Israelites worried that images would inevitably become fetishes; that is, they were concerned that people would forget that images are merely representations and start to idolize them, venerating them as though they were incarnations of the divine. Therefore, Yahweh warns his people in the following terms:

Thou shalt have no other gods before me. Though shalt not make unto thee any graven image, or any likeness of anything that is in heaven above, or that is in the earth beneath, or that is in the water under the earth. Though shalt not bow down thyself to them, nor serve them: for I the Lord thy God am a jealous God, visiting the iniquity of the fathers upon the children unto the third and fourth generation of them that hate me. (King James Bible, 1977, Exodus 20:3)

Why is the command so powerful and the punishment so harsh? Because the Israelites were aware that the human will is weak, and faulty understanding will lead to improperly distinguishing between the sign and the thing for which it stands. The power of the image is so great that people inevitably would come to mistake the image of God for God himself. Theologically, two important considerations explained this prohibition. First, to worship an image was to turn away from the idea that the image was said to represent. An image is only a material object and is, therefore, inferior to the ideal notion of the divine. This is a plain and rather loud echo of Plato, who also saw the material world (things below the divided line in his theory of knowledge) as inferior 
Scholarly and Research

Communication

VOLUME 12 / ISSUE 1 / 2021 and subject to change. So, in the Hebraic tradition, there is an actual injunction against thinking along these same lines. Just as Plato saw a moral obligation to pursue the truth and leave the world of materiality behind, the early Israelites were determined to prevent the faithful from making a similar error.

The second reason for the harshness of Yahweh's prohibition against graven images is that they are graven: that is, people make them; they are products of human labour. This suggests that in worshipping the image or icon we ourselves have created, we are worshipping our own labour power. Hence, the Old Testament is especially aniconic (against icons) in its condemnation of images, for to use images in the practice of worship is to risk substituting the image for the reality behind it.

\section{Idolatry and 9/11}

Another example of the way we might confuse images for reality is found in Baudrillard’s (1995) “The Gulf War Did Not Take Place." Many literal-minded readers took great offense to this book (which was a slim volume of only three essays) because the title suggests that Baudrillard had become callous and unfeeling regarding the loss of human life in the first Gulf War military campaign. But reading things literally is not always the best practice, for Baudrillard was speaking about the image of the war, not the war itself. In fact, Baudrillard's criticism was that the war had become an image, a kind of idolatry, a failure to understand the matter-spirit dichotomy. Slavoj Žižek (1999), writing in the New Left Review, said:

Let us recall what went on in the final American assault on the Iraqi lines during the Gulf War: no photos, no reports, just rumors that tanks with bulldozer-like shields in front of them rolled over Iraqi trenches, simply burying thousands of troops in earth and sand. What went on was allegedly considered too cruel in its sheer mechanical efficiency, too different from the standard notion of a heroic face-to-face combat, that images would perturb public opinion and a total censorship blackout was strictly imposed. Here we have the two aspects joined together: the new notion of war as a purely technological event, taking place behind radar and computer screens, with no casualties, and the extreme physical cruelty too unbearable for the gaze of the media - not the crippled children and raped women, victims of caricaturized local ethnic "fundamentalist warlords", but thousands of nameless soldiers, victims of anonymous and efficient technological warfare. When Baudrillard made the claim that the Gulf War did not take place, this statement could also be read in the sense that such traumatic pictures that stand for the Real of this war were totally censored. (p. 78)

Thus, image and reality were ultimately confounded. And rather than deal with the atrocities of the war, the military decided it was better to deal with the images of those same atrocities by censoring them. Saying the war did not take place is Baudrillard's rather sly critique about a system that cares more for images than for human lives.

\section{Barthes on images and rhetoric}

Barthes (1980) has written a good deal about images, and never with such insight as in his book Camera Lucida. In this volume, Barthes discusses at length the way the camera functions as a means of documentation, focusing especially on the way that photo- 
graphs capture an image of things as they were (when photographed) and not as they are now, famously referring to this as the experience of having-been-there. This notion makes (common)sense, but it also occasions some rather metaphysical posturing, for this view on photography positions death as a preeminent aspect of the photographic process (after all, even the dead can be rediscovered in photographs as having-beenthere). This is not to say that the condition of having-been-there and the relation between this position and the notion of death are logically deficient. It is only to say that some readers have found Camera Lucida's preoccupation with relating photography and death a bit too one-sided, even deterministic. Barthes' idea that photographs have no future and can only remind us of what has passed is sometimes also seen as too melancholy. In fact, Walter Benjamin's views of photography stand in stark contrast to Barthes' ideas, for Benjamin saw photos as bringing the past constantly into the present in a productive and even celebratory fashion. ${ }^{6}$ Where Barthes refers to the havingbeen-there of photography, Benjamin (1931) notes the photographer's ability to direct us to "the here and now" (p. 507). Nonetheless, Barthes' notion of photography as a freezing of a particular moment in which the object (or person) was there has been deeply influential for subsequent theorists of photography.

These thoughts lead to an interesting discussion regarding the metaphysics of presence, a notion derived from Martin Heidegger's (1962) phenomenology that appears to have had at least a modest influence on Barthes' thinking. But I want to pursue a different though related question, one that arises from the fact that Barthes, in seeking to address the rhetorical power of the photographic image, is compelled to admit that not all photographs "speak" to him and that most theories of photography fail to address his own experience as a viewer of photographic images. What most of these theories fail to observe is our highly individualized nature of appreciation. In other words, if photographs have the power to influence, persuade, sadden, or distress the viewer, then we would need to know about that viewer's personal history to determine why one particular photograph and not another is captivating and affectively compelling. And in following this approach - the approach that says some, but not all, photographs will engage individual viewers-Barthes (1980) argues throughout Camera Lucida that the only way he can speak intelligently about pictures is to speak exclusively of those photographs that actually interest him. The corollary is that he must, thereby, ignore going into lengthy discussions of famous photographs, which, he confesses, he often finds boring. This makes Camera Lucida a very personal book, but in spite of the subjectivity of this approach, the argument Barthes develops to account for his idiosyncratic understanding of photographic images provides important and relevant commentary that achieves a universal appeal.

Barthes speaks of photos in relation to two key terms: studium and punctum. The first refers to the general background meaning of the photo. The second, the punctum, refers to that aspect of the photograph that punctures the viewer's complacency and draws the viewer into an experience of the sensual contemplation of the image. The punctum is that aspect of a photograph that appeals to you or to me, even if it does not seem to be part of the photographer's original purpose. You may look at a photo and ask yourself, "Why is she wearing those shoes?" or, "I can't stop looking at this particular person though he's on the margin of the frame because he looks intoxicated." The
VOLUME 12 / ISSUE 1 / 2021 


\section{Scholarly and Research} Communication

VOLUME 12 / ISSUE 1 / 2021

punctum, in other words, is an arresting element in the photograph that we often respond to without necessarily being aware of why it draws our attention. Studium and punctum are almost equivalent to the more common semiotic idea of denotation and connotation. That aspect of Barthes' thinking about photography is revealed in one of his earlier books.

Barthes' (1977) collection of essays Image - Music - Text contains a short essay called "Rhetoric of the Image." This essay was published originally in French in 1964, and it is interesting to note how much of Camera Lucida (Barthes, 1980) is anticipated by things he says in this earlier essay. "Death of the Author" is probably the most famous essay in this book-it is certainly the most controversial-but Image - Music - Text is also important for the way that it shows Barthes developing a set of analytic practices shaped by his commitment to structural semiotics, even as he starts to move away from that model into a more obvious form of ideology critique. "Rhetoric of the Image" is only twenty pages long, but, as with much of Barthes, it is so dense that it requires a significant amount of unpacking.

First, Barthes (1977) begins by analyzing an ad for a brand of pasta called Panzani (see Figure 2). He is interested right away in the fact that the advertisement has text; that is, there are captions to help establish the meaning of the image as

Figure 2: Advertisement for Panzani pasta

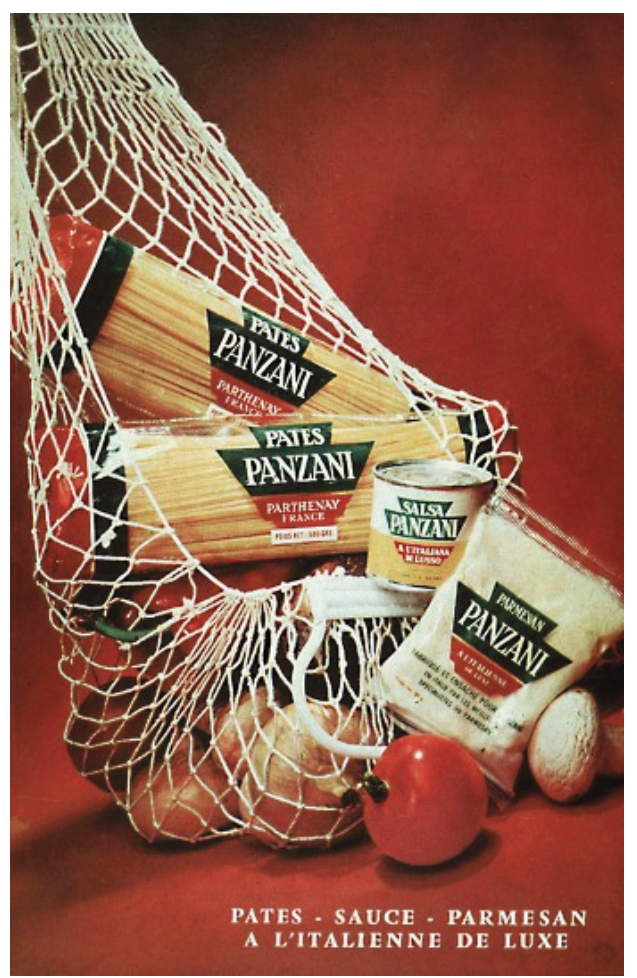

an advertisement and to advance its rhetorical properties as an inducement to buy a particular commodity. As a Frenchman, he is also drawn to the very sound of Panzani, which, he claims, has a particular assonance (or sound) that conveys Italianicity. The neologism of Italianicity is certainly interesting, especially because he regards the idea of Italianicity as an act of interpellation and, therefore, sees it as being folded into a larger concern with ideological processes. But for our purposes, most of what he says in respect to Italianicity can be regarded as an aside, for though he returns to the concept later, Barthes really wants to focus on the image. While he later adds some further comments on the textual dimensions of the ad, we can put those to one side for the moment.

Regarding the image itself, Barthes suggests that there are really four signs at work. The first is a sign of having returned from the market; the signifier of this sign is a bag with items spilling out. These objects (the shopping bag and the food) signify freshness; they may also indicate the idea of a resistance to prepackaged foods and thus contain a political implication. The image might also suggest someone who cooks daily, an evocative idea that speaks directly to familial (and some would suggest maternal) notions of care and love. The persistent juxtaposition of fresh, uncooked food with prepackaged foods also serves to conceal the actual labour involved in turning raw ingredients into wholesome meals. Whichever way we decode it, this sign is clearly enunciated in the material objects on display and the associated signified of fresh food. 
The second sign, Barthes (1977) says, is related via a process he calls "relay to the text" (p. 41): the peppers, the tomatoes, and so on, all convey something (to a Frenchman, he admits) of Italianicity: these are commodities associated with Italian cuisine and Italian culture. He barely describes the final two signs, but these are the connection that he says is drawn between the produce and the tin of sauce, the implication being that the can contains precisely the uncooked food that is shown in the bag and, therefore, heightens our sense of the freshness of Panzani products. The fourth sign is a cultural one that he says most people will miss: the image evokes memories of nature morte, what English speakers refer to as still life as that concept is understood in painting. In other words, the image is meant to draw upon earlier traditions in, for instance, paintings of cornucopia and other representations of food as symbolizing nature, nourishment, and culture. The still life connects nature and culture by literally bringing nature into domestic spaces (counters, tables, and so on), and the Panzani advertisement capitalizes on that cultural association to add a certain amount of prestige to the representation.

Now having said all of this, Barthes wants to acknowledge the having-been-there of the image (we are back momentarily to Camera Lucida). It is possible, Barthes says, to discern a purely denotative aspect in an image, the Panzani advertisement included. Why? Because before you engage in your cultural analysis of Italianicity or mobilize your knowledge of the history of still life paintings, you face what Barthes (1977) calls the "letter of the image" (p.36): the image with no message attached, the condition of the items depicted in the picture as having-been-there. Hence, at the most elementary level, the image might be said to show a series of things that are only associated because they are in the same frame. Looking at this ad (and any advertisement or image one might presume) reveals that:

The photograph ... offers us three messages: a linguistic message, a coded iconic message, and a non-coded iconic message. ... It is certain that the distinction between two iconic messages is not made spontaneously in ordinary reading: the viewer of the image receives at one and the same time the perceptual message and the cultural message. (p. 36)

This separation into coded and non-coded iconic messages makes sense, Barthes alleges, because it is exactly how the linguistic message operates: we encounter a signifier and associate it with a signified. For example, when someone speaks, we first hear the sound of the word-its aspect as a signifier-before associating that signifier with a particular mental idea, the signified. Once brought into union, the signifier and signified produce a meaningful sign. It should be the same with images, he says, so that if we are to move to a cultural understanding of images-that is, if we are to recognize them as coded (signs) - we must first begin with the non-coded iconic image; it is this noncoded iconic message that functions as a signifier.

Now, some critics of Barthes would immediately object that the photographed object must still have been arranged, framed, lighted, and so on, that it is not all that "pure." Barthes (1977) recognizes this but insists that the photographer's choices constitute the transition rather than the transformation of the photographed object. And it is in the fact that we receive "at one and the same time the perceptual message and the cultural message" (p. 36) that the ideological implications of visual rhetoric are made manifest. 
Scholarly and Research Communication

VOLUME 12 / ISSUE 1 / 2021
Barthes (1977) tells us that all images-he is relying on the Panzani advertisement (see Figure 2) as a stand-in for all images-have multiple levels at which signs are operative. To use his language, he sets out the distinction between "the literal message and the symbolic message" (p. 42). By "literal," Barthes means the non-coded message of the iconic aspect, and by "symbolic," he means the coded message. His reintroduction of the idea of the photographer's choice at this point makes this distinction more difficult to hold on to, but this is precisely Barthes' aim. In fact, perhaps we can better understand this confusion by posing it as a question: Is it ever really possible to say that an image such as the Panzani advertisement has only a literal level of meaning? That is, is there really any such thing as a pure image, one that is devoid of all cultural meaning? Is it possible to agree with Leni Riefenstahl (1935) and argue that Triumph of the Will was only pure history, not a propaganda film (see Sontag, 1980)? Where does the "purity" of the image in its uncoded iconic aspect come from?

Barthes (1977) suggests that there may indeed be something to the idea that the Panzani ad (see Figure 2) is just a picture at one level, that it is just a series of objects photographed as a document of their having existed somewhere in time (the having-beenthere of the image, again) and in that sense, pure. But to be able to say this, to be able to imagine a completely neutral, uncoded, and denotative depiction of objects in a photograph, he says that we would have to figure out how to get rid of the different cultural associations that come to mind when we see such an image. We have to "evict" (his word) these higher-level associations (such as Italianicity) to achieve what he calls an "Edenic state of the image" (p. 42).7 So, pure denotation-imagistic denotation devoid of all connotations - would be utopian, ideal, perfect in some way but perhaps practically unrealizable. (You can see something of Plato's thinking here.) In Barthes' words:

This utopian character of denotation is considerably reinforced by the paradox ... that the photograph (in its literal state), by virtue of its absolutely analogical character, seems to constitute a message without a code. (pp. 42-43)

This is an important point. Barthes tells us that when we look at images, we are deceived into believing that one aspect of the photograph, one characteristic of photographic images, is that they are fundamentally true in relation to their utopian denotations. That is, we might see a photograph and say it is just what it is: a photograph without any coded intentions, hidden meanings, or purposes beyond something we could call pure representation. Barthes then draws an interesting contrast, claiming that drawings are always already coded; when we look at artwork, that is, we know, owing to the manner in which paintings or drawings are produced, that they are rule governed in one way or another (they subscribe to an artistic tradition, for instance, or evoke a certain artistic style). We would not look at a hand-drawn image and describe it as possessing some form of purely iconic denotative meaning. (Some of McLuhan's thinking could be applied here.) By contrast, photographs seem to possess a denotative purity that remains outside of the coded cultural world of interpretative practices. Only when we decide to interpret a photograph do its connotative possibilities emerge. Indeed, Barthes goes on at some length to suggest why movies, like drawings, are heavily coded in ways that photographs resist. 
Barthes (1977) has now finally given his theory of the rhetoric of images. Because denotations are non-coded, they appear natural, and if we then are to engage in the task of providing connotative readings, we might transpose the natural truth of denotation to the cultural truth-actually, the ideology_of connotation. Here is one way he describes this:

The denoted image, to the extent to which it does not imply any code (the case with the advertising photograph), plays a special role in the general structure of the iconic message which we can begin to define ... the denoted image naturalizes the symbolic message, it innocents the semantic artifice of connotation, which is extremely dense, especially in advertising. (p. 45)

Thus, for Barthes, the idea of the literal denotation speaks to a naïve tendency to transpose the truth of that message to the cultural realm, and to accept that what we see at the cultural level is as true as the documentary truth of literalism.

Barthes (1977) summarizes his argument concerning the persuasiveness of images (mainly photographs, of course) in the following terms. It is a dense and difficult passage.

We can now understand that it is precisely the syntagm of the denoted message which "naturalizes" the system of the connoted message. (p. 51)

This is complicated, but the point is not that difficult when you parse the citation closely. Barthes says that images are rhetorical because we read the denoted messagethe literal, uncoded iconic aspect-as a kind of indexical truth, and then we see the connotation of the message-the coded aspect-also as true. But the truth of the coded aspect is only alleged, manufactured from the transposition of assent from uncoded to coded message. Because photographs are highly motivated (intensely iconic), it is possible to be persuaded of the purity of their representation. And once we accept that an image just is, we are more liable to accept that the cultural implication expressed in the photograph also just is. In the Panzani advertisement (see Figure 2), the reality of the literal message that includes fresh vegetables, noodles, a string bag-all the items that constitute Italianicity-is taken as the guarantee of the truth that Panzani is itself fresh, delicious, and objectively Italian. The having-been-there condition of the food, pasta, shopping bag, and so on is indisputable; it is a truth produced in the act of photographic practice. The mistake we make is to imagine that the truth of denotative representation can be transferred to the symbolic realm - the coded dimension-and treated at both levels as equivalent. Barthes' point, then, is to show that pure denotation is a fallacy, despite his acknowledgement of the compelling power of the image to make it appear as though denotation without cultural coding is possible.

\section{Paul Messaris' technique for visual analysis}

Barthes' work provides a theoretical approach more than it offers a guidebook for doing visual rhetoric-though I will add that I have myself used Barthes' ideas concerning the rhetoric of the image in some of my film writing. However, to get to a more practical approach, we can look to Paul Messaris (1997) and his book Visual Persuasion: The Role of Images in Advertising. In this volume, Messaris sets out a method of sorts for analyzing images. His goal, as he states in the title of his book, is to better understand the role of images in the world of advertising, but his method, if we 


\section{Scholarly and Research}

\section{Communication}

VOLUME 12 / ISSUE $1 / 2021$ can call it a full-blown method, could easily be applied in other cases. In order to test out both Messaris' method and the suggestion that it might be applicable beyond advertising, we need to be clear on what Messaris argues.

Messaris begins by pointing out that all modes of communication are characterized by their semantic and syntactic properties. If you focus on the semantic properties, you are focusing on how objects relate to their meanings. Semantic questions are, thus, questions of how things come to mean. Semantic problems arise when people do not share a common understanding, for instance, or where meaning is unclear owing to cultural factors. The semantic dimension of communication, he posits, is generally the one we first think about when considering what goes on in conveying messages.

The second way of thinking about a mode of communication is in terms of its syntactic properties. Syntax is generally defined by the way the units of a communication system are arranged and combined to form larger meaning units. Syntax is not entirely unre-

lated to meaning, of course, because certain rules must be followed if a specific communicational exchange is to be meaningful. Just putting the requisite words on the page with no concern for word order can produce a meaningless sentence despite the fact that all of the necessary components for a meaningful statement are present. In English, for instance, we usually expect every sentence to have a subject and a verb, and we further expect a certain logical arrangement of these components will be followed. So, in a sense, syntax is merely a set of combinatory rules, but following these rules is essential for grammatically correct sentences. It is also the case that combination and choice (syntax) play a role in narratives, including films and novels. Organization, then, is as important as meaning.

Having pointed out the dual concerns of communication, Messaris goes on to point out that the domain of semantics contains several other considerations, one of which is semiotics. Semiotics concerns itself with meaning in the study of signs, and though he recognizes a range of semiotic methods is available, Messaris opts to utilize C.S. Peirce's (2011) system of semiotics. ${ }^{8}$ Peirce distinguished signs into three sorts: icons, indexes, and symbols. An icon is characterized by similarity to its referent; an index is a causal or existential trace of its referent; and a symbol is related to its referent solely by convention.

\section{Semantic properties of images}

Messaris' goal, then, is to apply this classification system to the study of images; that is, what are the semantic and syntactical properties particular to images? He begins by inquiring into the semantic properties of images, and this presents him with the following question: what are the iconic, indexical, and symbolic qualities of images? His first move, then, is to examine images/pictures from the iconic standpoint, and here he suggests pictures are clearly iconic. Images will, in some important respect or another, resemble the thing that they represent. This claim might raise problems in relation to certain kinds of icons (can we really represent an incorporeal being such as God?), but these are the kind of problems we can put aside for the moment.

On the subject of indexical signs, Messaris makes an interesting point. Whether a picture or image is produced photographically, on film/video, or by other electronic

McCarron, Gary. 2021. Lecture 7: Visual Persuasion. Scholarly and Research Communication, 12(1). doi:10.22230/src.2021v12n1a375 
means, it has to have been produced by a kind of physical trace from its referent. A picture of any object is produced by the way that light reflecting off the object interacts with the camera, for instance, and the subsequent picture is indexical in that it bears a causal and/or existential relation to its referent. Again, Messaris might be stretching things here somewhat, but his argument is sufficiently logical.

Finally, he notes that symbolic signs do not easily apply in the case of pictures. At least in terms of his position, the semantic properties of communication are essentially exhausted at the iconic and indexical. He is aware, of course, that symbolic signs can have a role in images, as in the case of maps or technical diagrams, but he considers this connection to be tenuous at best and decides that he will focus only (or at least mainly) on the iconic and the indexical in his analysis.

\section{SyNTACTIC PROPERTIES OF IMAGES}

The syntactic properties of images are more interesting, perhaps because, as Messaris points out, it is not something that people tend to think about when analyzing images, and it is certainly not something that scholars have spent much time researching. It is true, as he indicates, that filmmakers rely on specific conventions to develop spatial and temporal arrangements and relationships among the images they are working with, but it is much harder to develop complex linguistic relations with images than it is with verbal or written language. Moreover, many of the cinematic techniques that we might associate with propositional syntax as it is practiced in verbal communication are highly variable and rather context dependent. Parallel editing, for instance, can be used for a range of purposes, showing us a causal relation in one case, a metaphysical connection in another, and so on. Of course, the context of the film will generally set things out clearly enough, but Messaris' point is that we are generally forced to use these contextual cues in a way that might not be present with verbal communication.

In linguistic communication, we make arguments, comparisons, and we direct our listeners' attention to things such as conditionality and causality, as Messaris points out. We can show the relation between things by saying, "if-then" or, "better than." With words I can say, "I am taller than you," or, "if you were quicker, you might have prevented the goal." These are illustrations of propositional syntax, and it is clearly one of the most important elements of syntax for effectively communicating. It is particularly important in the world of rhetoric and verbal persuasion, for propositional syntax enables us to present information in a range of forms that can be interpreted as threatening, cajoling, imploring, and so on. But visual communication lacks an explicit propositional syntax and would, therefore, seem to be terribly deficient in the realm of persuasiveness. Analogies, contrasts, causal claims, and other kinds of propositions cannot be advanced in images, Messaris says, and it is for this reason that one of the most significant things we can say about the syntactical properties of visual communication is that it has none. But this leads him to argue that because there is no obvious interpretive commonality when it comes to propositional syntax and vision-that is, because context is so crucial in deciphering what kind of proposition is being advanced when images are being used-it is more appropriate to speak of the indeterminacy of visual propositional syntax rather than an outright absence. And from here, it is a short step to his pronouncement that this propositional indeterminacy is not a deficiency in the 


\section{Scholarly and Research}

\section{Communication}

VOLUME 12 / ISSUE 1 / 2021 domain of images but a fundamental strength, especially in the case of advertising. Whether this is the case with all images, or whether it is something particular to advertising images and pictures, is a subject we can discuss further as a theoretical problem in the field of visual persuasion.

\section{IMPLICATIONS OF ICONICITY}

Messaris then summarizes his ideas according to the implications of iconicity, indexicality, and syntactical indeterminacy. Let us review these quickly, beginning with the implications of iconicity (remember that Messaris does not discuss the implications of symbolism, as he sees the symbolic dimension as it is understood in semiotics to have too little applicability in the field of visual persuasion).

The first implication of iconicity, Messaris argues, is that iconicity conveys powerful affective information. Pictures are surrogates, he says, for real-life visual encounters, and so they can elicit many of the same emotional responses that would have been conjured in the case of an actual flesh-and-blood encounter. Thus, Messaris (1997) indicates how advertisers can use touch-up techniques to alter marketing images to make them more attractive by making them more emotionally engaging. He discusses things such as altering pupil sizes in models; using a range of camera techniques, such as close-ups, in political debates; and even the attempt to place what he refers to as "gender or sexual connotations into the formal or stylistic features of images" (p.xv) (e.g., ads for feminine products using backgrounds with soft contours).

The second implication of iconicity according to Messaris is that in advertising images, the affective dimensions of images will produce more effective marketing campaigns internationally owing to the presumed universality of human images, human emotions, and so on. He seems to accept that this proposition has limited truth, however, and then cites reasons for believing that it may not be the case that images with their affective and emotional qualities have a global appeal after all. This may be so, but it raises questions about globalization, cosmopolitanism, and the hybrid identities that could also be explored in this context.

\section{IMPLICATIONS OF INDEXICALITY}

Messaris (1997) then moves on to discuss the implications of indexicality. This is more straightforward in some respects but more complicated in others. First, recall his point that photographs and other images bear the trace of their referent in either a causal or existential manner. The photographic record, he points out, serves a mainly documentary function; that is, the photograph serves to implicate the actual referent in the original task of producing the image. The celebrity endorser, to borrow his example, can be imagined as having sat for the photograph, rather than just as having agreed to have his/her name used in advertising copy. Indexicality, he argues, should "be counted as a distinctive feature of visual persuasion" (p. xvii) because this documentary potential provides the image with a mark of authenticity. Despite the fact that photographs can lie, as Messaris acknowledges, he is convinced that the potential for images (photos in particular) to be deceptive is minor compared to their stake in realism. This is a contentious argument, and one that has only increased since he first wrote his book. 
IMPLICATIONS OF SYNTACTICAL INDETERMINACY

If the indexicality and iconicity are two "positive" characteristics of visual persuasion, Messaris says that syntactical indeterminacy is a negative trait in that propositional syntax is something visual images lack. Visual syntax lacks any of the conventional devices that we use with verbal language to convey certain kinds of relations, including causality, metaphor, analogy, and so on. But rather than see syntactical indeterminacy as a deficiency, Messaris (1997) suggests at least two reasons for thinking it might actually be of benefit in the context of visual persuasion. The first is that without propositional syntax, the image requires greater involvement/participation on the part of the viewer. His second point is that because images cannot express explicit arguments, they are given greater latitude in respect of the sorts of associations they can depict.

In the case of the first point, the idea of audience participation has long been noted as an important consideration in rhetoric. McLuhan (1964) famously argued for this position in drawing a distinction between hot and cool media, suggesting that the latter were those that engaged people through their incompleteness to bring more of their own thinking and ideas into the interpretive process.

On the second point, Messaris claims that because images are without the capacity for propositional syntax, they have a distinct advantage in the domain of persuasiveness as they are less constrained by convention than verbal communication. He includes the example that cigarette advertisements that juxtapose images of tobacco with vistas of "vigorous outdoor activity" are both commonplace and preposterous. He suggests the implicitness of the connection drawn in these visual montages is different from the explicitness that we would expect of verbal expressions. This enables the image maker to make associations that will seem ludicrous but are of fundamental social and cultural value.

Finally, Messaris points out that these sorts of visual allusions that rely on an implicit association possibly serve a function that is sometimes ignored by critics of advertising. To the critic who says that marketers are just using sex and other forms of desire as lures to draw in customers, Messaris responds that this might be far less common than we think, even in cases where attractive people are featured or where sexual imagery is implied through various visual innuendos. Rather, Messaris argues that the implicitness of visual syntax enables people to make associations that they might be wary of doing in verbal communication. I might openly use a product endorsed by a celebrity I admire to publicly pledge my allegiance to the value(s) I imagine are implied by the association of that particular celebrity with that particular product. But I may be embarrassed to state my allegiance to those values. So, I use a product and trust that others see me in the way I imagine that the product will position me. It is easier to get into your cool car and drive away looking cool than it is to go around trying to convince people that you are cool. Hence, it is the implicit nature of images that works so well for advertising. It might also be the case that this is why images are generally considered so powerful, because they work with an incomplete, indeterminate syntax that is dependent on a common pool of associations.

With Barthes, then, we get an interesting theoretical model about the rhetorical power of images, and with Messaris we get a model for actual analysis. With our earlier discus- 


\section{Scholarly and Research}

\section{Communication}

VOLUME 12 / ISSUE 1 / 2021 sion of idolatry, we have seen that our fascination and fear of images has a deep history, and with the fact of imagistic immediacy, we are also able to recognize some of the way that this fascination (and this fear) becomes a source of power for visual representations. Finally, in the modern world, the appetite for images is even greater than it was when Wordsworth complained about the Illustrated London News in 1850, so perhaps the question we need to address is whether we feel that being more aware of this power has made us more protected from its effects.

\section{Notes}

1. Anticipations of Neil Postman's (1985) work can be detected in Wordsworth's poem.

2. Much of the information related here is told in James Bradley's (2000) historical recounting. Research conducted in the past several years now suggests that Ira Gagnon was not, in fact, among the men shown in Rosenthal's photograph. See Shawne Wickham (2019) for an account of this and other controversies related to the photograph.

3. Academic interest in the historical record pertaining to Iwo Jima and the translation of those events into cinema has resulted in several critical assessments, including an edited anthology of responses to filmmaker Clint Eastwood's 2006 film, Flags of our Fathers (Schubart \& Gjelsvik, 2013).

4. Although most of Loftus' work has been published in professional psychology journals two of her books are widely available, Witness for the Defense: The Accused, the Eyewitness, and the Expert Who Puts Memory on Trial (Loftus, 1992) and Eyewitness Testimony (Loftus, 1996).

5. I cannot speak about this at length, but you probably can see some resemblance between these views and the current so-called post-truth age of fake news. Not being able to tell the truth from the latest conspiracy theory is a sign that people are liable to nefarious forms of indoctrination.

6. Benjamin's (1931) ideas about photography are spread across many of his books. Perhaps the best place to begin is his text A Little History of Photography.

7. The idea that one might relate the perfectly neutral experience of the denotative level to the morally perfect world of Eden is intriguing. It would seem to suggest that once sin was introduced into Eden through the fall of Adam and Eve, the perfection was destroyed in making choices possible. That is, once Adam and Eve knew the difference between good and evil having eaten fruit from the forbidden tree, they were compelled to make decisions about how to behave in order to choose only the good and avoid sin. This would connect to the idea that when we look at an image, we have to choose our interpretation, a notion that connects sinfulness to the burden of choice. A purely denotative level is a level stripped of all prospects of interpretive activity.

8. Peirce's complete work is collected in eight volumes and is written in extremely dense prose. A shorter and helpful work is Philosophical writings of Peirce (Peirce, 2011).

\section{References}

Aristotle. (2001). Metaphysics (W.D. Ross, Trans.). In R. McKeon, The basic works of Aristotle

(pp. 682-926) New York, NY: The Modern Library.

McCarron, Gary. 2021. Lecture 7: Visual Persuasion. Scholarly and Research Communication, 12(1). doi:10.22230/src.2021v12n1a375 
Bacon, Francis. (1973). The advancement of learning. London: J. M. Dent \& Sons. (Originally published in 1605.)

Barthes, Roland. (1977). Image - music - text (S. Heat, Trans.). New York, NY: Hill and Wang.

Barthes, Roland. (1980). Camera lucida: Reflections on photography (R. Howard, Trans.). New York, NY: Hill and Wang.

Bateson, Gregory. (2000). Steps to an ecology of mind. Chicago, IL, \& London, UK: Chicago University Press. (Originally published in 1972.)

Baudrillard, Jean. (1983). Simulations. (P. Foss, P. Patton, \& P. Beitchman, Trans.). New York, NY: Semiotext(e), Inc.

Baudrillard, Jean. (1995). The Gulf War did not take place (P. Patton, Trans.). Bloomington, IN, \& Indianapolis, IN: University of Indiana Press.

Benjamin, Walter. (1999). A little history of photography. In M.W. Jennings, H. Eiland, \& G. Smith (Eds.), Walter Benjamin: Selected writings (Vol. 2, Part 2, 1931-1934, pp. 507-530). Cambridge, MA: Belknap Press.

Bradley, James. (2000). Flags of our fathers. New York, NY, \& Toronto, ON: Bantam Books.

Dwan, Allen (Director). (1949). Sands of Iwo Jima. Studio City, CA: Republic Pictures Corporation.

Eastwood, Clint (Director). (2006). Flags of our fathers. Universal City, CA: Dreamworks pictures, Warner Bros., Amblin Entertainment, \& Malpaso Productions.

Ferguson, Niall. (2009). Ascent of money: Financial history of the world. Harmondsworth, UK: Penguin Books.

Hawkes, David. (1996). Ideology (2nd ed.). London, UK, \& New York, NY: Routledge Books.

Heidegger, Martin. (1962). Being and time (J. McQuarrie \& E. Robinson, Trans.). Oxford, UK, \&

Cambridge, MA: Blackwell Books. (Originally published in 1927.)

King James Bible. (1977). Nashville, TN: Thomas Nelson, Inc.

Loftus, Elizabeth. (1992). Witness for the defense: The accused, the eyewitness, and the expert who puts memory on trial. New York, NY: St. Martin's Press.

Loftus, Elizabeth. (1996). Eyewitness testimony. Cambridge, MA: Harvard University Press.

McLuhan, Marshall. (1964). In W. Terrence Gordon (Ed.), Understanding media: The extensions of man (Critical ed.). Corte Madera, CA: Gingko Press, Inc.

Messaris, Paul. (1997). Visual persuasion: The role of images in advertising. Thousand Oaks, CA, \& London, UK: SAGE Publications.

Peirce, Charles. (2011). In J. Buchler (Ed.), Philosophical writings of Peirce (Rev. ed.). New York, NY: Dover Books.

Postman, Neil. (1985). Amusing ourselves to death: Public discourse in the age of show business. New York, NY: Viking Penguin Books.

Riefenstahl, Leni. (1935). Triumph of the will. URL: https://www.publicdomainmoviess.com/movie /83-triumph-of-the-will [September 26, 2021].

Schubart, Rikke, \& Gjelsvik, Anne (Eds.). (2013). Eastwood's Iwo Jima: Critical engagements with "Flags of our Fathers" and "Letters from Iwo Jima." New York, NY: Columbia University Press.

Shell, Marc. (1982). Money, language and thought: Literary and philosophical economies from the medieval to the modern era. Berkeley, CA, \& Los Angeles, CA: University of California Press.

Simmel, Georg. (1978). The philosophy of money (T. Bottomore \& D. Frisby, Trans.). London, UK, \& New York, NY: Routledge. (Originally published in 1920.)

Sontag, Susan. (1980). Fascinating fascism. In S. Sontag (Ed.), Under the sign of Saturn (pp. 73-105). New York, NY: Farrar-Strauss-Giroux.

Tavris, Carol, \& Aronson, Elliot. (2007). Mistakes were made (but not by me). New York, NY, \& London, UK: Harcourt Books.
Scholarly and Research Communication

VOLUME 12 / ISSUE 1 / 2021 
Scholarly and Research

\section{Communication}

VOLUME 12 / ISSUE 1 / 2021
Wickham, Shawne. (2019, Oct. 19). Flag raising wasn't what made Ira Gagnon a hero of Iwo Jima. New Hampshire Sunday News. URL: https:/www.unionleader.com/news/history/flag-raising-wasnt -what-made-rene-gagnon-a-hero-of-iwo-jima/article_8750f45a-34bc-5ac5-87c8-dfafe6e4cb26 .html [September 26, 2021].

Wordsworth, William. (1994). The collected poems of William Wordsworth. Hertfordshire, UK: Wordsworth Editions.

Žižek, Slavoj. (1999). Against the double blackmail. New Left Review, 1(234), 76-82. 